\title{
CALCULATION OF PAYBACK PERIOD MINERAL WOOL WITH LONGITUDINAL FIBERS OF ITE PARISO (PAREXLANKO)
}

\author{
Dr Nikolay Vatin* \\ St.Petersburg State Polytechnical University, Russia \\ Dr Alexander Gorshkov \\ St.Petersburg State Polytechnical University, Russia \\ Alexandra Kazimirova \\ St.Petersburg State Polytechnical University, Russia \\ Kirill Gureev \\ St.Petersburg State Polytechnical University, Russia \\ Darya Nemova \\ St.Petersburg State Polytechnical University, Russia
}

The article presents a calculation of an energy-saving payback system aimed at enhancing thermal protection of enclosing structures of a panel-assembled building in use by means of the ITE PARISO thermal insulation products. Examples are given of how to calculate the simple payback period of extra insulation of buildings' exterior walls by ITE PARISO slabs and of how to calculate the payback period taking into account the growth of rates for thermal energy.

Keywords: Thermal insulation, Refurbishment work, Extra thermal insulation, Energy efficiency in buildings

\section{INTRODUCTION}

The higher the level of thermal protection of exterior enclosing structures (walls, windows, coverings, etc.) the lower are the heat losses through them and the less heat needs to be supplied to the building to make up for the heat loss. Thus, the increase of heat protection (thermal insulation) of exterior enclosing structures can reduce the heat energy loss and, thereby, cut the spending on the use of the building. One of the existing buildings' energy saving and energy efficiency improving methods is based on this principle.

Most of the residential facilities being currently used in the Russian Federation do not meet the regulatory requirements in terms of thermal protection of enclosing structures. Since 2000 , following amendment No.3 to SNiP II-3-79* (Russian building standard) and subsequent approval, based on this amendment, of SNiP 23-02-2003 standard (since 2012, SP 50.13330.2012- construction standard), the requirements applied to the level of thermal protection of enclosing structures have toughened significantly. It means that all the buildings erected before 2000 do not meet the current requirements applied to thermal protection, i.e. they are obsolete and need renovation. Insulating of enclosing structures has to be the main action of energy efficiency reconstruction [16-22].

Used as a material for external thermal insulation of structure walls are rock wool slabs with longitudinal arrangement of ITE PARISO fibers (manufactured by PAREXLANKO research laboratory, I'Isle d'Abeau, France. AlphaStroi Service Ltd, St Petersburg, Russia, is a representative of the French trademark PAREXLANKO). The ITE PARISO slab specifications are shown in Table 3. The ITE PARISO slabs are designed for use as a thermally insulating layer in façade systems with a thin coat of plaster in new construction, reconstruction, major and routine repair of buildings and structures for different applications.

\section{LITERATURE REVIEW}

The following scientists made a big contribution to the solution of energy saving problems and enhancement of energy efficiency: Yulia Yuryevna Ivakina, Sergey Pavlovich Kutyev, Pavel Vladislavovich Monastyryov, Nikolay Ivanovich 
Vatin, Vera Murgul, Alexander Viktorovich Sadchikov, Yekaterina Aleksandrovna Latyntseva, and Manvel Sergoyevich Akopyan [1-41].

In her work, Yu.Yu.Ivakina developed an installation for experimental determination of rock wool slabs' likely emission. Using the micro-structural and chemical analysis method she established that the rock wool used for 5 years is physically, chemically and biologically resistant to corrosion. S.P.Kutyev established a multi-factorial dependence between the physico-mechanic parameters of individual layers and strength performance of a finished two-layer rock wool product. Also, he established the dependence of physico-mechanic and thermal-engineering specifications of a finished two-layer rock wool product on the density of upper and lower layers and their ratio. Finally, he established the dependence of strength of rock wool products on the binding agents content. P.V.Monastyryov used such an investigation method as laboratory experiments to study the changes, over time, of thermo-physical and physico-mechanic properties of rock wool slabs under the impact of operating factors. He determined the essential factors characterizing the geometrical and thermo-physical properties of elements of ventilated facades and significantly affecting the thermal engineering uniformity of thermally insulated exterior walls. A.V.Sadchikov experimentally established the air permeance of rock wood insulating slabs and foam polystyrene of different thickness. He has developed a methodology of determining thermal losses of an area of construction in the ventilated façade with regard to the longitudinal air filtration in the thermal insulator. He determined the influence of the insulator type on the actual resistance to heat transfer in an area of enclosing structure with regard to the longitudinal air filtration in the insulator. Ye.A.Latyntseva proposed a technology of insulating industrial high-temperature systems with rock wool based on a new type of binder. The technology employs the pouring process right on the facility site. She established that the operating strength of rock wool products based on alum silicate binder is higher than that of those based on phenolic alcohols and aided by the modified alumochromphosphate binder. M.S.Akopyan detected new physico-mechanical properties of insulators acquired during their filling into narrow, long channels, with employment of methods developed expressly for this purpose. He investigated the devices that uniformly distribute the stress on the rock wool insulator as it is filled into shallows and cavities. To the same end he proposed the optimum versions of those devices.

However, despite the large amount of investigations on this subject, the effective method of insulating the enclosing structures by rock wool slabs featuring longitudinally arranged fibers has not received due attention.

Goals of the research work:

- The goal of this research work is calculation of the payback period for the energy-saving efforts aimed at enhancing the thermal protection of facades (exterior walls) of a panelassembled structures commissioned before 2000 (the method of insulating the enclosing structures by rock wool slabs featuring longitudinally arranged fibers).

Tasks of the research work:

- to calculate the simple payback period;

- to calculate the complex payback period taking into account the growth of thermal energy rates.

- In calculating the simple payback the following is omitted: rate of discount, inflation, credit interest (in case of using borrowed funds for thermal insulation of the structure's exterior walls), growth of thermal energy rates.

With reference to this model we shall consider that the discount rate corresponds to the inflation and they fully defray each other in the period under consideration. Also, let us presume that no borrowed funds (credits) are used for insulating the facades. In the event of a block of flats, the façade insulation is made using the funds accumulated by the residents for the general overhaul whilst in case of owners of a single-apartment building those will be the householder's personal funds. Thus we obtain an approximate model which can subsequently be made more complex by introducing coefficients and functional dependences. In calculating the complex payback we shall take into consideration the growth of rates for thermal energy. The following pattern of the rate growth, 5,10 and $15 \%$, will be considered.

Taken for an object of investigation is a panelassembled block of flats.

\section{INITIAL DATA FOR CALCULATION}

Taken as reference data for climate in the design work were:

in the event of the residential block of flats - the climatic conditions of St Petersburg.

The nominal climatic and thermal energy pa- 
rameters of the building for St Petersburg were accepted as per SP 131.13330 [2] construction standard. They are shown in Table 1.

The geometric characteristics of the facades of the building under consideration are not shown because the work calculates operating loss of thermal energy and capital spending on extra insulation shown for $1 \mathrm{~m} 2$ of exterior facades. The geometric characteristics of the facades of the building under consideration are not shown because the work calculates operating loss of thermal energy and capital spending on extra insulation shown for $1 \mathrm{~m} 2$ of exterior facades. Based on the data shown in Tables 1, calculation is made of the basic value of the required resistance to heat transfer of exterior enclosing structures $R_{0}^{\text {req }}$ . The value $R_{0}^{\text {req }}$ (see note to Table 2 SP 50.1330 standard) is calculated by the formula:

$R_{0}^{r e q}=a \cdot D D H P+b$

DDHP - degree-days of heating period (see data of Tables 1 and 2);

$a, b$ - coefficients whose values must be taken from Table 3 SP 50.13330 construction standard for relevant task packages; for exterior walls of residential buildings $a=0,00035, b=1,4$.

Based on the obtained initial data let us calculate, using formula (1), the basic values of the required resistance to heat.

$R_{0}^{\text {req }}=a \cdot D D H P+b=0,0035 \cdot 4537+1,4=2,99\left(\mathrm{~m}^{2} \cdot{ }^{\circ} \mathrm{C} / \mathrm{W}\right)$

For external walls of a residential block of flats in St Petersburg, we shall obtain:

Used as a material for the buildings' external wall insulation are rock wool slabs with longitudinal arrangement of ITE PARISO fibers (manufacturer: PAREXLANKO research laboratory, I'Isle d'Abeau, France. Specifications of the ITE PARISO slabs are shown in Table 2.

The ITE PARISO slabs are designed for use as a thermally insulating layer in façade systems with a thin coat of plaster in new construction, reconstruction, and major and routine repair of buildings and structures for different applications (see TS for use of façade insulation system in compliance with the GOST 4640-93 standard) [06-09].

Table 1: Nominal climatic conditions for residential buildings in St Petersburg

\begin{tabular}{|l|c|c|c|}
\hline Parameter & Parameter designation & Unit of measurement & $\begin{array}{l}\text { Nominal } \\
\text { value }\end{array}$ \\
\hline Nominal temperature of external air & $\mathrm{t}_{\mathrm{H}}$ & ${ }^{\circ} \mathrm{C}$ & -24 \\
\hline $\begin{array}{l}\text { Mean temperature of external air } \\
\text { during heating period }\end{array}$ & $\mathrm{t}_{\text {от }}$ & ${ }^{\circ} \mathrm{C}$ & -1.3 \\
\hline Heating period duration & $\mathrm{z}_{\mathrm{OT}}$ & day/year & 213 \\
\hline Degree-day of heating period & $\mathrm{DDHP}$ & ${ }^{\circ} \mathrm{C}$ day/year & 4537 \\
\hline Nominal temperature of internal air & $\mathrm{t}_{\mathrm{B}}$ & ${ }^{\circ} \mathrm{C}$ & 20 \\
\hline
\end{tabular}

Table 2: Characteristics of rock wool slabs with longitudinal arrangement of ITE PARISO fibers

\begin{tabular}{|l|c|}
\hline \multicolumn{1}{|c|}{ Parameter name } & Numeric value \\
\hline Density, $\mathrm{kg} / \mathrm{m}^{3}$ & 150 \\
\hline $\begin{array}{l}\text { Heat conductivity } \lambda_{25}, \mathrm{~W} /(\mathrm{m} \cdot \mathrm{K}), \\
\text { not more than }\end{array}$ & 0.038 \\
\hline $\begin{array}{l}\text { Nominal heat conductivity for operating conditions } \\
\mathrm{A} \lambda_{\mathrm{A}}, \mathrm{W} /(\mathrm{m} \cdot \mathrm{K}), \text { not more than }\end{array}$ & 0.045 \\
\hline $\begin{array}{l}\text { Nominal heat conductivity for operating conditions } \mathrm{B} \\
\lambda_{5}, \mathrm{~W} /(\mathrm{m} \bullet \mathrm{K}), \text { not more than }\end{array}$ & 0.048 \\
\hline Vapor permeability, $\mathrm{mg} /(\mathrm{m} \bullet \mathrm{h} \cdot \mathrm{Pa})$, not more than & 0.3 \\
\hline $\begin{array}{l}\text { Compression strength at } 10 \% \text { deformation, } \mathrm{kPa}, \mathrm{not} \\
\text { more than }\end{array}$ & 0.35 \\
\hline
\end{tabular}




\section{CALCULATION OF SIMPLE PAYBACK}

Calculation for a block of flats in Saint Petersburg . Let's consider the model below.

The existing building was erected before 2000 and is located in St Petersburg. Let's assume that the cited resistance to heat transfer of external walls meets requirements of the construction standard SNiP II-3-79* and amounts to 1.0

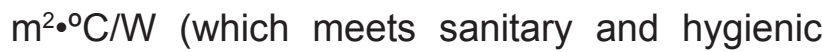
requirements applied to the climatic conditions of St Petersburg). Accordingly, the coefficient of heat transfer of external walls is: $\mathrm{U}=1.0 \mathrm{~W} /$

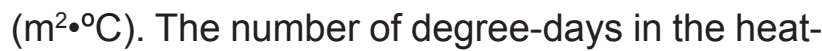
ing period (DDHP) for residential buildings in St Petersburg, as Table 1 shows, is $4537^{\circ} \mathrm{C} \cdot$ day. The heating is centralized (supplied by the city's heat power plant. The cost of thermal energy is 1,351.25 RUB/Gcal, incl. VAT (resolution No.589-p of St Petersburg Committee on Rates and Tariffs dated 20.12.2012. It is necessary to insulate the external walls of the building so that they would satisfy the regulatory requirements $\left(2.99 \mathrm{~m} 2 \cdot{ }^{\circ} \mathrm{C} / \mathrm{W}\right.$ as per construction standard SP 50.13330) [7-16]. It is also necessary to calculate the payback period of work on extra insulation. Taken for the insulator is ITE PARISO rock wool, with subsequent plastering of the wall over the insulation layer.

Let's calculate the required thickness of insulator $\delta_{r e q} \mathrm{~m}$. We use the following formula:

$\delta_{r e q}=\left(R_{0}^{r e q}-R_{0}^{i n i t}\right) \cdot \frac{\lambda_{\text {ins }}}{r}$

$R_{0}^{r e q}$ - the required value of cited resistance to heat

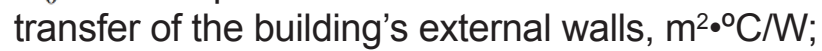

$R_{0}^{\text {init }}$ - initial (actual) value of cited resistance to heat transfer of the building's external walls be-

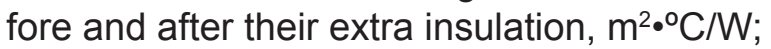
$\lambda_{\text {ins }}$ insulator heat conductivity, $\mathrm{W} / \mathrm{m} \cdot{ }^{\circ} \mathrm{C}$; this is accepted for operating conditions $\mathrm{E}\left(\lambda_{\mathrm{b}}\right)$;

$r$ - coefficient of thermal-technical uniformity of the extra layer of insulation.

The formula (2) disregards the thermal resistance of the plaster layer because it is negligently small compared to the thermal resistance of the insulation layer.

Let's assume, for the rock wool insulator of the ITE PARISO system, a heat conductivity coefficient under $\bar{B}\left(\lambda_{\mathrm{b}}\right)$ operating conditions equal to 0.048 $\mathrm{W} / \mathrm{m}^{\circ}{ }^{\circ} \mathrm{C}$ ), whereas the coefficient of thermal uniformity $r$ will be equal to 0.87 (with 4 expansion bolts, $6 \mathrm{~mm}$ diameter, on $1 \mathrm{~m}^{2}$ of the wall area).

The required value of resistance to heat transfer for external walls of residential buildings as applied to the climatic conditions of St Petersburg (DDHP $=4537^{\circ} \mathrm{C} \cdot$ day) $R_{0}^{r e q}$ amounts to $2.99 \mathrm{~m}^{2}{ }^{\circ} \mathrm{C} / \mathrm{W}$. The value of resistance to heat transfer equal to 2.99 $\mathrm{m}^{2 \cdot{ }^{\circ} \mathrm{C}} \mathrm{W}$ corresponds to the coefficient of heat transfer $\mathrm{U}=0.335 \mathrm{~W} / \mathrm{m}^{2}{ }^{\circ} \mathrm{C}$. Let us assume that the actual value of the cited resistance to heat transfer $\left(R_{0}^{\text {init }}\right)$ is substantiated by thermo-technical measurements and is equal to $1.0 \mathrm{~m}^{2}{ }^{\circ} \mathrm{C} / \mathrm{W}$ [33-38].

Then the required thickness of the insulation layer $\delta_{\text {req }}$ will amount to:

$\delta_{\text {req }}=\left(R_{0}^{\text {req }}-R_{0}^{\text {init }}\right) \cdot \frac{\lambda_{\text {ins }}}{r}=(2,99-1,0) \cdot \frac{0,048}{0,87} \approx 0,11(\mathrm{~m})$

Accordingly, for further economic calculations let's assume that the required thickness of the insulation is $110 \mathrm{~mm}$. The wall construction under consideration is schematically shown in Figure 1 Using the formula (3):

$$
\Delta \ni=Э_{1}-\ni_{2}=Q_{1} \cdot c_{T}-Q_{2} \cdot c_{T}=\frac{0,024 U_{1} \cdot D D H P}{1163}{ }^{2} c_{T}-\frac{0,024 U_{2} \cdot D D H P}{1163} \cdot c_{T}=\left(U_{1}-U_{2}\right) \cdot \frac{0,024 D D H P}{1163} \cdot c_{T}
$$

where $\Delta \ni$ - the difference of operating costs (losses of thermal energy over $1 \mathrm{~m}^{2}$ during a single heating period) for the building's external wall before $\left(\ni_{1}\right)$ and after insulation $\left(\ni_{2}\right)$; $\mathrm{C}_{\mathrm{T}^{-}}$the cost of thermal energy, Rub/Gcal ; $\mathrm{U}_{1,2}$ - the heat transfer coefficient of building envelopes $\left(U=\frac{1}{R_{0}}\right)$; let's calculate, for the instance dealt with, the difference of operating costs (losses of thermal energy over $1 \mathrm{~m}^{2}$ during a single heating period) for the building's external wall before and after insulation. Thus we'll obtain:

$$
\Delta \ni=\left(U_{1}-U_{2}\right) \cdot \frac{0,024 \cdot D D H P}{1163} \cdot c_{T}=(1-0,335) \cdot \frac{0,024 \cdot 4537}{1163} \cdot 1351,25 \approx 84,1\left(\frac{r u b}{\mathrm{~m}^{2}}\right)
$$

Capital spending on extra insulation of an exterior wall of the existing panel-assembled building in Saint-Petersburg $(\Delta K)$ is $1974.6 \mathrm{Rub} / \mathrm{m}^{2}$.

Divide the $\Delta K$ values by the $\Delta \ni$ values below. We

obtain the simple payback period for insulation of the exterior wall of the existing building at the insulator thickness of $110 \mathrm{~mm}$ (Figure 1):

$$
T=\frac{\Delta K}{\Delta \ni}=\frac{1974,6}{84,1}=23,4(\text { years }) \text {. }
$$




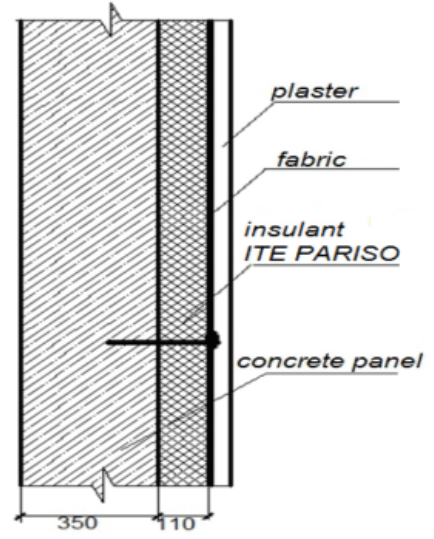

Figure 1: Diagram of a panel-assembled block of flats' exterior wall construction

It should be noted that the payback period $\mathrm{T}=23,4$ years was obtained without considering the growth of rates for thermal energy.

Therefore, the obtained value of the payback period equal to 23,4 years can be regarded only as an evaluative figure.
It should be pointed out that in case of a thicker insulation (> $110 \mathrm{~mm}$ ), the simple payback period will shorten (will be less than 23.4 years) because the capital outlays will grow insignificantly in comparison with the operating cost reduction. This is so because the main costs in the capital outlays sector are those of plastering and will remain unchanged for any insulator thickness [22-28].

\section{CALCULATION OF THE RECOUPMENT PERIOD OF EXTRA THERMAL INSULATION OF FACADES TAKING INTO ACCOUNT THE GROUTH OF HEAT RATES}

The heat rates in Russia grow each year. This leads to the growth of spending on use and maintenance of buildings. Table 3 shows the heat energy rates growth pattern in Saint Petersburg during 2006-2011. Table 4 shows the rates growth pattern for Saint Petersburg citizens, i.e. the growth of cost of heat per year (in percent) relative to the previous year.

Table 3: Dynamics of growth of tariffs for thermal energy in St. Petersburg from 2006 to 2011 at the centralized heating of buildings

\begin{tabular}{|c|c|l|}
\hline Year & $\begin{array}{c}\text { Rate figure, Rub/Gcal } \\
\text { (VAT inc.) }\end{array}$ & \multicolumn{1}{c|}{ Basis } \\
\hline 2006 & 500.40 & $\begin{array}{l}\text { Resolution N 100-p of the St Petersburg Administration of 16 } \\
\text { November 2005 }\end{array}$ \\
\hline 2007 & 575.46 & $\begin{array}{l}\text { Resolution N 123-p of the St Petersburg Administration's } \\
\text { Committee on Rates and Tariffs of 15 November 2006 }\end{array}$ \\
\hline 2008 & 650.00 & $\begin{array}{l}\text { Resolution N 139-p of the St Petersburg Administration's } \\
\text { Committee on Rates and Tariffs of 31 October 2007 }\end{array}$ \\
\hline 2009 & 795.73 & $\begin{array}{l}\text { Resolution N 141-p of the St Petersburg Administration's } \\
\text { Committee on Rates and Tariffs of 19 November 2008 }\end{array}$ \\
\hline 2010 & 931.00 & $\begin{array}{l}\text { Resolution N 199-p of the St Petersburg Administration's } \\
\text { Committee on Rates and Tariffs of 14 December 2009 }\end{array}$ \\
\hline 2011 & 1050.00 & $\begin{array}{l}\text { Resolution N 334-p of the St Petersburg Administration's } \\
\text { Committee on Rates and Tariffs of 13 December 2010 }\end{array}$ \\
\hline
\end{tabular}

Table 4: Pattern of heat energy rate growth (in relative terms)

\begin{tabular}{|c|c|}
\hline Years (from $\ldots$ to) & Accrued cost of heat energy relative to the previous year, $\%$ \\
\hline from 2006 to 2007 & +15.0 \\
\hline from 2007 to 2008 & +13.0 \\
\hline from 2008 to 2009 & +22.4 \\
\hline from 2009 to 2010 & +17.0 \\
\hline from 2010 to 2011 & +12.8 \\
\hline On average in one year $\left(\Delta c_{T}\right)$ & +16.0 \\
\hline
\end{tabular}


So, in the period under consideration (from 2006 to 2011) the average figure of relative growth of rates for heat energy per year $\Delta c_{T}$ amounted to $16 \%$. If this figure is taken as a reference for forecasting the cost of heat energy in the coming years, then the presented scheme shows that each 5 years the heat rates are due to grow by 2.1 times $\left(1,16^{5}\right)$. It means that if this dynamics persists further, then in 10 years' time they may grow in a geometrical progression by 4.4 times $\left(1.16^{10}\right)$ and so on. At least, until now, as the data of Table 4 show, this has been the case $(1,050.0$ $\mathrm{rub} / \mathrm{Gcal}(2011) / 500.4 \mathrm{rub} / \mathrm{Gcal}(2006)=2.1)$.
The Russian Federation Government plans to reduce the growth of housing and utilities rates. Thus far, however, it is unclear how it will be done in real life. Therefore, let's consider three likely scenarios: mean annual growth of rates for heat power by $5 \%$; mean annual growth of rates for heat power by $10 \%$; mean annual growth of rates for heat and power by $15 \%$.

Calculation of payback periods is shown in tables $5,6,7$. The calculation results is shown in figure $2,3,4$. As can be seen from them, taking into account the growth of rates for thermal energy the payback period is greatly reduced.

Table 5: Calculation of a payback period (the average annual growth of rates for heat power by $5 \%$ )

\begin{tabular}{|c|c|c|c|c|c|c|c|c|c|}
\hline & \multicolumn{9}{|c|}{ Financial performance, rub } \\
\hline & \multicolumn{9}{|c|}{ by years } \\
\hline & 1 & 2 & 3 & 4 & 5 & 6 & 7 & 8 & 9 \\
\hline $\begin{array}{l}\text { Costs of insulation of } 1 \mathrm{~m}^{2} \text { of } \\
\text { a facade }\end{array}$ & -1975 & & & & & & & & \\
\hline Saving of thermal energy & 84 & 88 & 93 & 97 & 102 & 107 & 113 & 118 & 124 \\
\hline \multirow[t]{2}{*}{ Balance with accumulation } & -1891 & -1802 & -1710 & -1612 & -1510 & -1403 & -1290 & -1172 & -1047 \\
\hline & 10 & 11 & 12 & 13 & 14 & 15 & 16 & 17 & 18 \\
\hline \multicolumn{10}{|l|}{$\begin{array}{l}\text { Costs of insulation of } 1 \mathrm{~m}^{2} \text { of a } \\
\text { facade }\end{array}$} \\
\hline Saving of thermal energy & 131 & 137 & 144 & 151 & 159 & 167 & 175 & 184 & 193 \\
\hline Balance with accumulation & -917 & -780 & -636 & -485 & -326 & -160 & 16 & 200 & 393 \\
\hline
\end{tabular}

Table 6: Calculation of a payback period (the average annual growth of rates for heat power by $10 \%$ )

\begin{tabular}{|c|c|c|c|c|c|c|c|c|c|}
\hline & \multicolumn{9}{|c|}{ Financial performance, rub } \\
\hline & \multicolumn{9}{|c|}{ by years } \\
\hline & 1 & 2 & 3 & 4 & 5 & 6 & 7 & 8 & 9 \\
\hline $\begin{array}{l}\text { Costs of insulation of } 1 \mathrm{~m}^{2} \text { of } \\
\text { a facade }\end{array}$ & -1975 & & & & & & & & \\
\hline Saving of thermal energy & 84 & 93 & 102 & 112 & 123 & 135 & 149 & 164 & 180 \\
\hline \multirow[t]{2}{*}{ Balance with accumulation } & -1891 & -1798 & -1696 & -1584 & -1461 & -1326 & -1177 & -1013 & -833 \\
\hline & 10 & 11 & 12 & 13 & 14 & 15 & 16 & 17 & 18 \\
\hline \multicolumn{10}{|l|}{$\begin{array}{l}\text { Costs of insulation of } 1 \mathrm{~m}^{2} \text { of a } \\
\text { facade }\end{array}$} \\
\hline Saving of thermal energy & 198 & 218 & 240 & 0264 & 290 & 319 & 351 & 386 & 425 \\
\hline Balance with accumulation & -634 & -416 & -176 & 88 & 378 & 698 & 1049 & 1435 & 1860 \\
\hline
\end{tabular}


Table 7: Calculation of a payback period (the average annual growth of rates for heat power by $10 \%$ )

\begin{tabular}{|c|c|c|c|c|c|c|c|c|c|}
\hline & \multicolumn{9}{|c|}{ Financial performance, rub } \\
\hline & \multicolumn{9}{|c|}{ by years } \\
\hline & 1 & 2 & 3 & 4 & 5 & 6 & 7 & 8 & 9 \\
\hline $\begin{array}{l}\text { Costs of insulation of } 1 \mathrm{~m}^{2} \text { of } \\
\text { a facade }\end{array}$ & -1975 & & & & & & & & \\
\hline Saving of thermal energy & 84 & 97 & 111 & 128 & 147 & 169 & 195 & 224 & 257 \\
\hline Balance with accumulation & -1891 & -1794 & -1683 & -1555 & -1408 & -1238 & -1044 & -820 & -563 \\
\hline & 10 & 11 & 12 & 13 & 14 & 15 & 16 & 17 & 18 \\
\hline $\begin{array}{l}\text { Costs of insulation of } 1 \mathrm{~m}^{2} \text { of a } \\
\text { facade }\end{array}$ & & & & & & & & & \\
\hline Saving of thermal energy & 296 & 340 & 391 & 450 & 517 & 595 & 684 & 787 & 905 \\
\hline Balance with accumulation & $-267,1$ & 73,2 & 464,4 & 914,4 & 1432 & 2027 & 2711 & 3498 & 4403 \\
\hline
\end{tabular}

Economic effect, rub

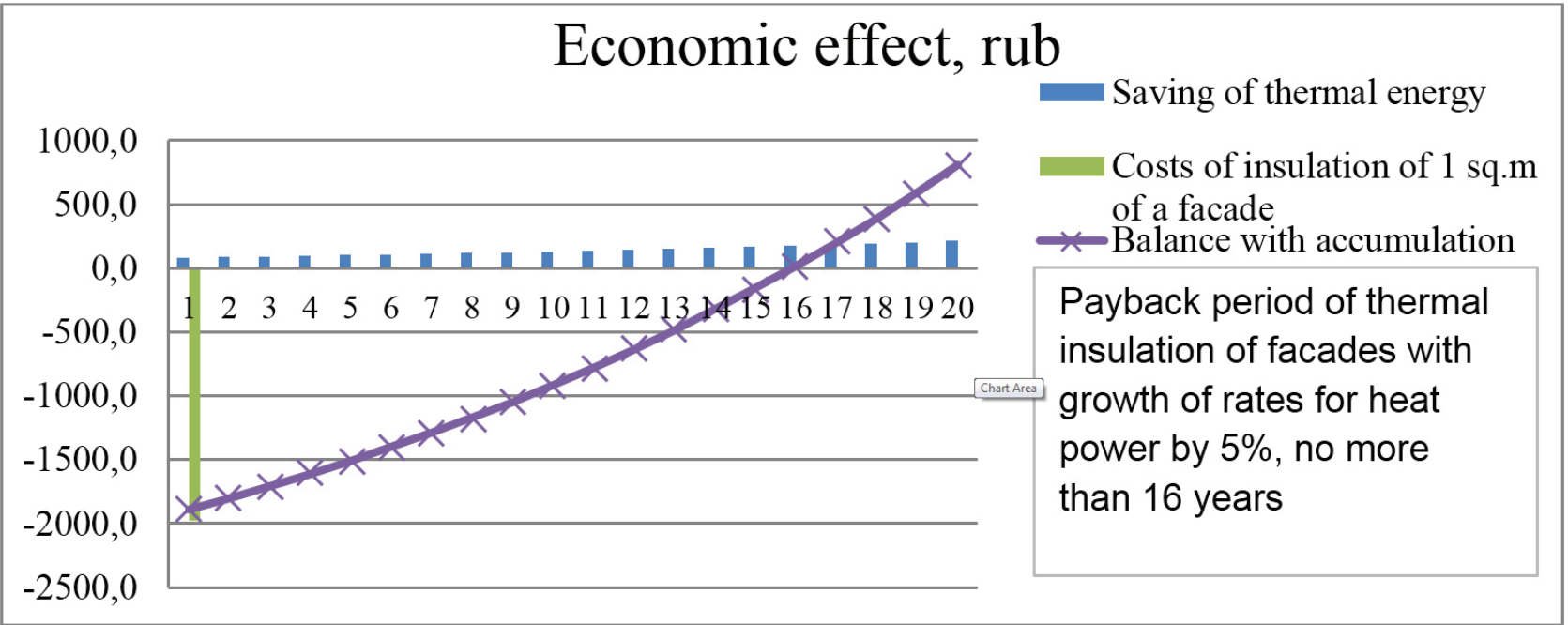

Figure 2: Economic effect in terms of money at growth of rates by $5 \%$

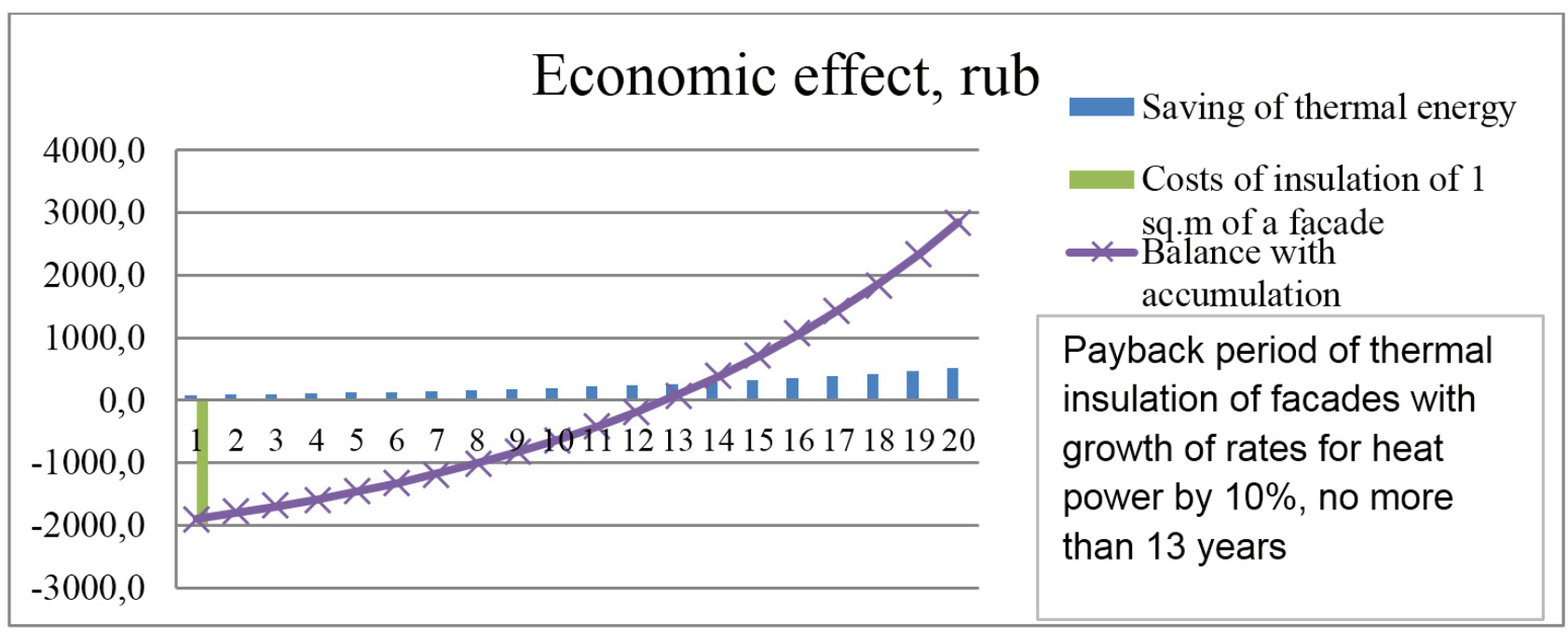

Figure 3: Economic effect in terms of money at growth of rates by $10 \%$ 


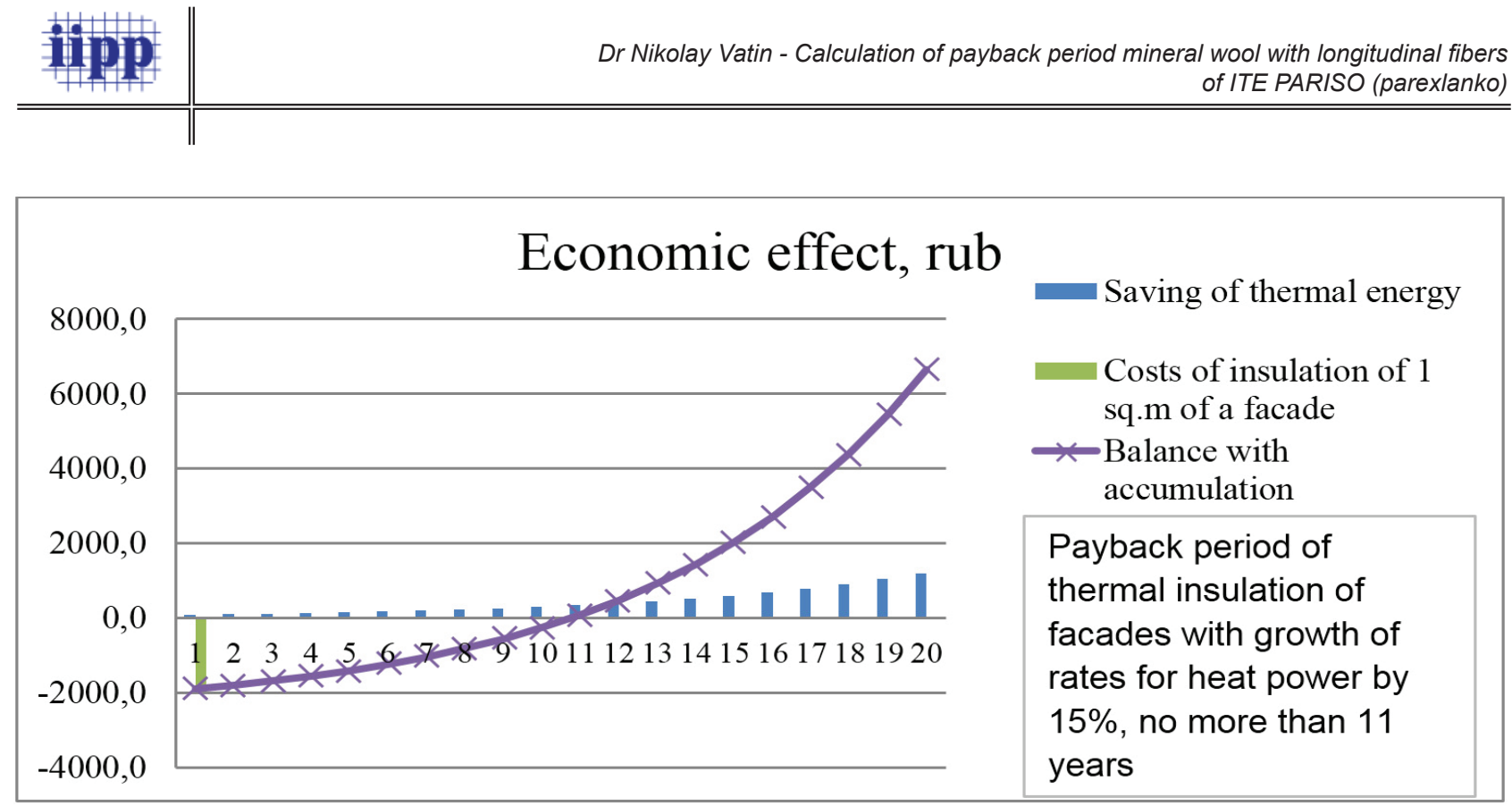

Figure 4: Economic effect in terms of money at growth of rates by $15 \%$

\section{CONCLUSIONS}

In this article, the payback periods for the energysavings efforts aimed at enhancing the thermal protection of facades (exterior walls) of a panelassembled structures commissioned before 2000 are calculated (the method of insulating the enclosing structures by rock wool slabs featuring longitudinally arranged fibers). For this goals:

- the simple payback period is calculated, the payback period is 23,4 years;

- the complex payback period taking into account the growth of thermal energy rates is calculated, Payback period of thermal insulation of facades with growth of rates for heat power by $5 \%$, no more than 16 years, by $10 \%$, no more than 13 years, by $15 \%$, no more than 11 years.

\section{REFERENCES}

1) Alihodzic, R., Murgul, V., Vatin, N., Aronova, E., Nikolić, V., Tanić, M., Stanković, D. (2014): Renewable Energy Sources used to Supply Pre-school Facilities with Energy in Different Weather Conditions. Applied Mechanics and Materials. Vol. 624. pp. 604-612

2) Aronova, E., Murgul, V. (2013): The evaluation of the appropriateness for using solar energy technologies in the historical building of SaintPetersburg and the climatic conditions of the North-West region, Architecture and Modern Information Technologies, 2 (23), pp. 97-117

3) Aronova, E., Radovic, G., Murgul, V., Vatin, N. (2014): Solar Power Opportunities in Northern Cities (Case Study of Saint-Pe- tersburg). Applied Mechanics and Materials. Vols. 587-589, pp. 348-354

4) Bukhartsev, V.N., Petrichenko , M.R., (2001): Condition of mechanical-energy balance of an integral flow with a variable rate, Power Technology and Engineering , 35 (4) , pp. 189-194

5) Bukhartsev, V.N., Petrichenko , M.R., (2012): Nonsteady filtration in a uniform soil mass, Power Technology and Engineering , 46 (3) , pp. 198-200

6) Bukhartsev , V.N., Petrichenko , M.R., (2012): Problem of filtration in a uniform rectangular soil mass is solved by variational principles, Power Technology and Engineering , 46 (3) , pp. 185-189

7) Bukhartsev, V.N., Petrichenko, M.R., (2011): Approximation of the depression curve of the inflow to an ideal trench, Power Technology and Engineering. pp. 1-4

8) Gorshkov, A.S. (2010): Energy efficiency in construction: questions of rationing and measure for decrease in power consumption of buildings , Magazine of Civil Engineering. No. 1, pp. 9-13

9) http://www.dissercat.com/content/tekhnologiya-zapolneniya-pustot-ekstruzionnykh-panelei-mineralovatnym-uteplitelem/, retrieved on January 8th, 2014

10) http://www.dissercat.com/content/povyshenie-effektivnosti-ventiliruemykh-fasadov-smineralovatnym-uteplitelem/, retrieved on January 9th, 2014

11) http://www.dissercat.com/content/effektivnye-dvukhsloinye-mineralovatnye-izdeliya/, retrieved on January 9th, 2014

12) http://www. dissercat.com/content/teploizolyatsionnye-izdeliya-na-osnove-mineralno- 
go-volokna-i-alyumosilikatnoi-svyazki/, retrieved on January 9th, 2014

13) http://www.dissercat.com/content/fiziko-tekhnicheskie-i-konstruktivno-tekhnologicheskieosnovy-termomodernizatsii-ograzhdayus/, retrieved on January 9th, 2014

14) http://www.dissercat.com/content/vliyanieprodolnoi-filtratsii-vozdukha-v-uteplitele-nateplozashchitnye-svoistva-sten-s-nave/, retrieved on January 9th, 2014

15) Knatko , M. V., Efimenko , M. N., (2008): Ampere-second Pots. To a question of durability and energy efficiency of modern protecting wall designs of residential, office and production buildings, Magazine of Civil Engineering. No. 2 , pp. 50-53

16) Lazarevska, M., Milanovic, M., Knezevic, M., Cvetkovska, M., Trombeva-Gavriloska, A., Samardzioska, T. (2014): An artificial neural network prediction model for fire resistance of composite columns, Journal of Applied Engineering Science, Vol. 12, № 1, pp. 63-68

17) Manojlovic, A., Medar, O., Trifunovic, J., Vukadinovic, K. (2012): Cost of activities in public utility fleets, Journal of Applied Engineering Science, № 1 (10), pp. 9-14

18) Murgul, V. (2014): Features of energy efficient upgrade of historic buildings (illustrated with the example of Saint-Petersburg), Journal of Applied Engineering Science, Vol. 12 (1), pp. 1-10

19) Murgul, V. (2012): Improvement of the energy efficient properties of the houses in the historical area of Saint-Petersburg, Architecton: Proceedings of Higher Education, 4 (40) pp. 54-62

20) Murgul, V.: Solar energy in the reconstruction of urban environment of historic building Saint-Petersburg, Architecture and Modern Information Technologies, 2 (23) (2013), pp. 1-24.

21) Murgul, V.: Solar energy systems in the reconstruction of heritage historical buildings of the northern towns (for example SanktPetersburg). Journal of Applied Engineering Science, Vol. 12 (2) (2014), pp 121-128

22) Na Na Kanga, Sung Heui Choa, Jeong Tai Kimb (2012): The energy-saving effects of apartment residents' awareness and behavior, Energy and Buildings. Vol. 46, pp.112-122

23) Nemova, D., Murgul, V., Golik, A., Chizhov, E., Pukhkal, V., Vatin N. (2014): Reconstruction of administrative buildings of the 70s: the possibility of energy modernization, Jour- nal of Applied Engineering Science, Vol. 12, № 1, pp. 37-44

24) Paulauskayte, S., Lapinskene Century , (2011): Analysis of the efficiency of passive energy saving measures in buildings with large glazing area, Vestnik MGSU. No. 7, pp. 90-97

25) Pavlicic, N., Perazic, M., Djuric-Jocic, D., Knezevic, M. (2014): Engineering education in the field of civil engineering, Journal of Applied Engineering Science, Vol. 12, № 1, pp. 11-18

26) Petrichenko , R.M., Mezheritskii , A.D., (1989): Options in the quasi-stationary method of designing impulse turbines for supercharging internal combustion engine systems, Soviet energy technology (5) , pp. 13-17

27) Petrichenko, R.M., Shabanov, A.Yu., (1985): Hydrodynamics of Oil Film Under Internal Combustion Engine Piston Rings, Trudy LPI (411) , pp. 38-42

28) Petronijevic, P., Ivanisevic, N., Rakocevic, M., Arizanovic, D. (2012): Methods of calculating depreciation expenses of construction machinery, Journal of Applied Engineering Science, № 1 (10), pp. 43-48

29) Petrosova D. V. (2012): Air Filtering through the building envelope, Magazine of Civil Engineering. T. 28 . No. 2, pp. 24-31

30) Petrov , K.V., Sled , I.A., Eagles , O. A., Lynx , I.V., Urustimov , A.I. (2012): Competition "Architectural concept of building with zero energy consumption", Construction of unique buildings and structures. No. 1, pp. 53-60

31) Radovic, G., Murgul, V., Vatin, N.(2014): Fast urban development of Cetinje - old royal capital of Montenegro. Applied Mechanics and Materials. Vols. 584-586, pp. 564-569

32) Tayfun Uygunoğlua, Ali Keçebaşb. (2011): LCC analysis for energy-saving in residential buildings with different types of construction masonry blocks, Energy and Buildings. Vol. 43, Issue 9, pp. 2077-2085

33) Vatin , N.I., Mikhailova , T.N. 1986): computation of cross correlation function of induced potential for developed turbulent flow with axisymmetric mean velocity profile, Magnetohydrodynamics New York, N.Y. 22 (4) pp. 385-390

34) Vatin , N.I. (1985): Weight vector of a conduction transducer of a correlation flowmeter, Magnetohydrodynamics New York, N.Y. 21 (3) , pp. 316-320 
35) Vatin N., Gorshkov A., Nemova D., Staritcyna A., Tarasova D. (2014). The energy-efficient heat insulation thickness for systems of hinged ventilated facades. Advanced Materials Research Vols. 941-944. pp 905-920

36) Vatin N., Nazmeeva T., Guslinscky R. (2014) Problems of cold-bent notched c-shaped profile members. Advanced Materials Research. Vols. 941-944. pp 1871-1875

37) Vatin N., Havula J., Martikainen L., Sinelnikov A., Orlova A., Salamakhin S. (2014). Thin-walled cross-sections and their joints: tests and FEM-modelling. Advanced Materials Research Vols. 945-949. pp 1211-1215

38) Vatin V., Nemova D., Kazimirova A., Gureev K. (2014). Increase of energy efficiency of the building of kindergarten. Advanced Materials Research. Vols. 953-954 (2014) pp 1537-1544
39) Vuksanovic, D., Murgul V., Vatin, N., Aronova E. (2014): Shadowing impact on amount of power generated by photovoltaic modules. Applied Mechanics and Materials. Vols. 587589, pp. 342-347

40) Wei Li, Jinzhong Zhu, Zhimin Zhu. (2012): The Energy-saving Benefit Evaluation Methods of the Grid Construction Project Based on Life Cycle Cost Theory , Energy Procedia. Vol. 17, Part A., pp. 227-232

41) Xinhong Zhaoa, Congyu Mab, Pingdao Gub. (2012): Energy Saving Methods and Results Analysis in the Hotel, Energy Procedia. Vol.14, pp. 1523-1527

Paper sent to revision: 08.05.2014.

Paper ready for publication: 10.09.2014. 